\title{
An Investigation on the Competences of School Managers in Managing the Emotions of Teachers*
}

\author{
Mehmet Akif Helvacı, Hazal Takmak* \\ Faculty of Education, Usak University, Turkey
}

Copyright $\subset 2016$ by authors, all rights reserved. Authors agree that this article remains permanently open access under the terms of the Creative Commons Attribution License 4.0 International License

\begin{abstract}
The emotion management of others is among the new competences of school managers. Therefore, the purpose of this study is to determine the Competences of Managing the Emotions of Teachers by School Managers in terms of management processes according to the viewpoints of teachers and managers. The questionnaire was administrated to 261 teachers and 109 school administrators working in Uşak province during the 2015/2016 Academic Year. The data were analyzed by the SPSS (Statistical Package for Social Sciences) program. In the analyses of the study, a $t$-test and One Way Anova Test were used; in order to determine the group that caused the difference, a Tukey HSD test was used. The findings of the study are as follows: It was found that teachers' viewpoints related to the competence of managing the emotions of teachers of school managers are on the "quite" level in terms of decision-making, planning, communicating, organizing and assessment processes, while in terms of coordinating the results are on the "medium" level. It was determined that there are differentiations between teachers' viewpoints related to the competences of managing the emotions of teachers of school managers in terms of management processes regarding their gender, branch, school type, task type, seniority and educational status.
\end{abstract}

Keywords Emotion, Emotion Management, School Managers

\section{Introduction}

Emotions influence our lives during our daily lives as well as during our working lives, and guide our behavior ([17]; [29]). Anger, sadness, joy, love, hatred and similar emotions are experienced almost every day in nearly every organization, and these emotions profoundly influence other individuals in an organization and the organization itself [18]. These emotions also influence the relations of the employees in almost every aspect, from their perceptions of authority in the organization to their career targets [22].
Emotions not only appear in dramatic events, they also appear in our daily duties, but stay undetected; they also influence the professional performances of employees [13]. When the managers in an organization show due care for the emotions of their employees, and show this care in practice, the performance of the organization will improve [22].

If the relationships within an organization bring organizational success, the role expected from the managers is to influence the emotions of the employees in their organization. Meanwhile, the managers also direct the interpersonal relationships inside and outside the organization by creating the emotional heart of the organization [8]. When the literature is investigated it is observed that the concept of emotion management is defined by Niven [20], Keskin, Akgün and Yılmaz [16], Mayer and Salovey [19], Töremen and Çankaya [28], Andrieş [2], Gross and Thompson [14], Niven, Totterdell and Holman [21], and Pedersen [24] in various ways. When the common points of these definitions are considered, we can define emotional management as trying to influence and change the emotions and styles of expressing these emotions of individuals in a deliberate manner.

Emotional management aims to place the emotional interaction between the employees, employees-leaders, and employees-customers. One of the major sources needed for emotional management both at an individual level and at an interpersonal level is emotional intelligence [2]. Ashkanasy and Daus [4] state that emotions, and especially emotional intelligence, has become one of the most important matters in organizations in recent years, and emotional intelligence may be used as a method of coping with emotions in organizations by managers and employees. Emotional intelligence requires not only being able to manage one's own emotions, but also it requires being able to manage the emotions of other individuals. In order to do this, people must have knowledge of emotions, use them in an efficient manner, and assess and express them [11].

The relationship between leadership and intelligence is instinctive. Individuals whose emotional intelligence is high may organize their own emotions and the emotions of the other individuals, and use the emotional knowledge in 
Decision Making Processes in order to produce positive and creative results [4]. Individuals whose emotional intelligence levels are high have the ability to control their negative emotions, develop their positive ones, and manage the emotions of other individuals [19].

Pescosolido [32] claimed that leaders can influence the emotions of their employees in two ways. The first is to provide appropriate emotional reactions to the events happening in the workplace, and to transfer them to the employees by being a role model. The other is to create emotional experiences that connect the employees to each other and to increase their motivation [15]. Organizational studies show that emotional management is a basic property of efficient leadership. This property requires managing one's own emotions and those of other individuals [1]. Leaders are very well positioned for interpersonal emotional management ([11]; [15]); and when employees experience negative emotions, it is expected that the leaders intervene in an efficient and preventative manner [4]. Toegel, Kilduff and Anand [27] reported that when employees experience negative feelings, they expect their leaders to intervene in the situation and help them. A study conducted by Thiel, Griffith and Connelly [25] supports this proposition, and shows that leaders observe the behavior of employees and help them reduce their negative emotions.

One of the most important organizations in which the human factor and social relations in a society are at the forefront is an educational organization that improves the individual and integrates him/her with the society. For this reason, emotions have an important place in schools. It is especially important that teachers, who have the duty of raising human beings, have positive emotions. For this reason, knowing the situations that influence the emotions of the teachers and determining the influence of the managers on these situations will ensure that positive outcomes are reached regarding the teachers and their working environments ([3]; [6]). In this context, being able to influence and manage the emotions of teachers are among the new skills that are expected from school managers. For this reason, the problem of this study is to determine the level of the Competences of Managing the Emotions of Teachers by School Managers according to the viewpoints of the teachers and school managers. For this purpose, answers to the following sub-problems will be sought.

1. What are the Competence levels of school managers in Managing the Emotions of Teachers in the context of Decision Making, Planning, Communication, Organizing, Coordinating and Assessment Processes according to the viewpoints of teachers and school managers?

2. Do the viewpoints of the teachers and school managers vary in all management processes (Decision Making, Planning, Communication, Organizing, Coordinating and Assessment) according to the following variables?
a) Gender,
b) Branch,
c) Duty,
d) School Type,
e) Seniority,
f) Educational Status

\section{Method}

This study was conducted according to the relational survey model because of the consistency of this model with the topic and purpose of this study.

The range of this study consists of the school managers and teachers working in the schools of the Ministry of National Education in the city of Uşak during the 2015-2016 Academic Year. In order to determine the participants that would be included in the sampling, Layered Random Sampling was applied. The number of participants was determined from the groups in accordance with the percentages to form this range by using the Simple Random Sampling Method. In this context, the sampling of this study consists of 370 teachers and managers working in primary, secondary and high schools in the city of Uşak. $40.5 \%$ of the participants are Female, 59.5\% of the participants are Male; $29.7 \%$ of the participants work in primary schools, $45.4 \%$ of the participants work in secondary schools, $24.9 \%$ of the participants work in high schools.

The Emotional Management Behavior Scale of Managers in terms of the Management Processes developed by Çoruk and Akçay [10] was used in this study. There is personal information (Gender, branch, educational status, service years, etc.) in the first part of the questionnaire.

The 5-Point Likert Scale items in the "Assessment Scale of Competences of School Managers in Managing the Emotions of Teachers", which is in the second part of the questionnaire, were given points such as " $1=\mathrm{I}$ do not agree at all", " $5=\mathrm{I}$ completely agree". High points in the sub-dimension indicate that the school managers show more management of their emotions and behavior. In this context, the points of the scale express between 1.00-1.79 "None", between 1.80-2.59 "Little", between 2.60-3.39 "Medium level", between 3.40-4.19 "Fairly" and between 4.20-5.00 "Much".

In this context, the "Assessment Scale of Competences of School Managers in Managing the Emotions of Teachers" consists of six sub-dimensions. The Cronbach Alpha coefficients were calculated for the reliability of the measurements obtained in the whole and sub-dimensions of the scale. The Cronbach Alpha coefficients of the sub-dimensions were found to be 0.88 for the "Decision Making" sub-dimension; 0.91 for the "Planning" sub-dimension, 0.96 for the "Communication" sub-dimension, 0.96 for the "Organizing" sub-dimension, 0.86 for the "Coordinating" sub-dimension, 0.93 for the "Assessment" sub-dimension, and the Cronbach Alpha coefficient of the whole scale was found to be 0.98 . The findings show that the measurements obtained from the scale are at a reliable level ( $>.70)$.

The SPSS 17.0 package program was used in the analyses 
of the data to determine the "Assessment Scale of Competences of School Managers in Managing the Emotions of Teachers". In this context, the standard deviation values were calculated for each item in the sub-dimension part of the scale, and presented in tables. It was determined that the points obtained from the scale show a normal distribution. In this context, the independent samples t-test and One Way ANOVA tests were used in the analyses of the points obtained from the sub-dimensions of the scale in terms of the various variables; and in case there are significant differences, the Tukey HSD Test was used in order to determine the differences between the groups.

\section{Findings}

The analyses and findings of the problem of this study are given in this section. First, the levels of the competences of the school managers in managing the emotions of their teachers, and then the issue as to whether there is a difference according to some variables in the teachers' viewpoints are dealt with, and the relevant analyses and findings are provided.

As can be observed in Table 1, the teachers' viewpoints on the Competences of School Managers in Managing the Emotions of Teachers in terms of Management Processes in Decision Making, Planning, Communication, Organizing and Assessment processes are extremely high. The highest value out of the items (40 items) in the questionnaire is $=$ 4.02 on "M.3 They believe that if teachers have a positive spiritual status, this will facilitate the solving of the problem". The lowest value is $=2.93$ in "M.26They make small surprises to guide the emotions of the teachers in the direction of the organization".

Table 1. Teachers and School Managers' Viewpoints on the Competences of Managing the Emotions of Teachers by School Managers in Terms of Management Processes

\begin{tabular}{cccc}
\hline $\begin{array}{c}\text { Management } \\
\text { Processes }\end{array}$ & M & SD & $\begin{array}{c}\text { Competence } \\
\text { Level }\end{array}$ \\
\hline Decision Making & 3.77 & 0.86 & Fairly \\
\hline Planning & 3.54 & 0.90 & Fairly \\
\hline Communication & 3.69 & 0.88 & Fairly \\
\hline Organizing & 3.46 & 0.94 & Fairly \\
\hline Coordinating & 3.26 & 0.91 & Medium Level \\
\hline Assessment & 3.64 & 0.97 & Fairly \\
\hline
\end{tabular}

The Decision Making process attracts attention as the process in which the teachers had the highest level of participation in the Competences of School Managers in Managing the Emotions of Teachers $(M=3.77)$. However, it can also be observed that the participation of the teachers in the Coordinating Process is at the "I agree at medium level", and that the teachers agree at the lowest level with the Competences of School Managers in Managing the Emotions of Teachers $(\mathrm{M}=3.26)$.

Table 2. The t-Test Results of the Competences of Managing the Emotions of Teachers by School Managers according to the Gender Variable

\begin{tabular}{|c|c|c|c|c|c|c|c|}
\hline PROCESSES & Gender & $\mathbf{N}$ & $\mathbf{M}$ & SD & df & $\mathbf{T}$ & $\mathbf{p}$ \\
\hline \multirow{2}{*}{ Decision Making } & Female & 150 & 3.63 & .89 & \multirow{2}{*}{368} & \multirow{2}{*}{-2.430} & \multirow{2}{*}{$.016^{*}$} \\
\hline & Male & 220 & 3.85 & .82 & & & \\
\hline \multirow{2}{*}{ Planning } & Female & 150 & 3.35 & .95 & \multirow{2}{*}{368} & \multirow{2}{*}{-3.262} & \multirow{2}{*}{$.001 *$} \\
\hline & Male & 220 & 3.65 & .83 & & & \\
\hline \multirow{2}{*}{ Communication } & Female & 150 & 3.50 & .92 & \multirow{2}{*}{368} & \multirow{2}{*}{-3.474} & \multirow{2}{*}{$.001 * *$} \\
\hline & Male & 220 & 3.82 & .82 & & & \\
\hline \multirow{2}{*}{ Organizing } & Female & 150 & 3.34 & 1.01 & \multirow{2}{*}{368} & \multirow{2}{*}{-1.892} & \multirow{2}{*}{.059} \\
\hline & Male & 220 & 3.53 & .89 & & & \\
\hline \multirow{2}{*}{ Coordinating } & Female & 150 & 3.07 & .94 & \multirow{2}{*}{368} & \multirow{2}{*}{-3.303} & \multirow{2}{*}{$.001 * *$} \\
\hline & Male & 220 & 3.38 & .86 & & & \\
\hline \multirow{2}{*}{ Assessment } & Female & 150 & 3.45 & 1.01 & \multirow{2}{*}{368} & \multirow{2}{*}{-3.100} & \multirow{2}{*}{$.002 * *$} \\
\hline & Male & 220 & 3.76 & .93 & & & \\
\hline
\end{tabular}

$* p<.05 \quad * * p<.01$

According to the Gender Variable in Table 2, the viewpoints of the female and male teachers on the Competences of Managing the Emotions of Teachers by School Managers differ in favor of the male teachers in the Decision Making $[t(368)=-2.430, p<.05]$, Planning $[t(368)=-3.262, p<.01]$, Communication $[t(368)=-3.474, p<.01]$, Coordinating $[t(368)=-3.303, p<.01]$ and Assessment $[t(368)=-3.100, p<.01]$ Processes. 
Table 3. The $t$-Test Results of Competences of Managing the Emotions of Teachers by School Managers according to Branch Variable

\begin{tabular}{|c|c|c|c|c|c|c|c|}
\hline PROCESSES & Branch & $\mathbf{N}$ & $\mathbf{M}$ & SD & df & $\mathbf{T}$ & $\mathbf{p}$ \\
\hline \multirow{2}{*}{ Decision Making } & Class & 93 & 3.93 & .70 & \multirow{2}{*}{368} & \multirow{2}{*}{2.123} & \multirow{2}{*}{$.034^{*}$} \\
\hline & Branch & 277 & 3.71 & .90 & & & \\
\hline \multirow{2}{*}{ Planning } & Class & 93 & 3.71 & .72 & \multirow{2}{*}{368} & \multirow{2}{*}{2.271} & \multirow{2}{*}{$.024 *$} \\
\hline & Branch & 277 & 3.47 & .94 & & & \\
\hline \multirow[b]{2}{*}{ Communication } & Class & 93 & 3.87 & .76 & \multirow[b]{2}{*}{368} & \multirow[b]{2}{*}{2.328} & \multirow[b]{2}{*}{$.020^{*}$} \\
\hline & Branch & 277 & 3.62 & .91 & & & \\
\hline \multirow{2}{*}{ Organizing } & Class & 93 & 3.68 & .80 & \multirow{2}{*}{368} & \multirow{2}{*}{.628} & \multirow{2}{*}{$.009 * *$} \\
\hline & ranch & 277 & 3.38 & .97 & & & \\
\hline \multirow{2}{*}{ Coordinating } & Class & 93 & 3.44 & .81 & \multirow{2}{*}{368} & \multirow{2}{*}{.231} & \multirow{2}{*}{$.026^{*}$} \\
\hline & ranch & 277 & 3.20 & .93 & & & \\
\hline \multirow{2}{*}{ Assessment } & Class & 93 & 3.80 & .89 & \multirow{2}{*}{368} & \multirow{2}{*}{.929} & \multirow{2}{*}{.054} \\
\hline & Branch & 277 & 3.58 & .99 & & & \\
\hline
\end{tabular}

$* p<.05 \quad * * p<.01$

According to the Branch variable in Table 3, the viewpoints of the Class and Branch Teachers, who participated in the study, on competences of managing the emotions of teachers by school managers differ in favor of Class Teachers in Decision Making $[t(368)=2.123, p<.05]$, Planning $[t(368)=2.271, p<.05]$, Communication $[t(368)=2.328, p<.05]$, Organizing $[t(368)=2.628, p<.01]$, Coordinating $[t(368)=2.231, p<.05]$ processes.

Table 4. Anova Test Results of the Competences of Managing the Emotions of Teachers by School Managers according to the School Type Variable

\begin{tabular}{|c|c|c|c|c|c|c|c|}
\hline PROCESSES & School Type & $\mathbf{N}$ & $\mathbf{M}$ & SD & df & $\mathbf{F}$ & $\mathbf{p}$ \\
\hline Decision & Primary S. & 110 & 3.91 & .73 & 2 & 3.400 & $0.34 *$ \\
\hline \multirow[t]{2}{*}{ Making } & Secondary & 168 & 3.77 & .86 & 367 & & \\
\hline & High S. & 92 & 3.60 & .97 & 369 & & \\
\hline \multirow[t]{3}{*}{ Planning } & Primary S. & 110 & 3.68 & .79 & 2 & 2.252 & .107 \\
\hline & Secondary & 168 & 3.44 & .91 & 367 & & \\
\hline & High S. & 92 & 3.53 & .98 & 369 & & \\
\hline \multirow[t]{3}{*}{ Communication } & Primary S. & 110 & 3.83 & .80 & 2 & 2.188 & .114 \\
\hline & Secondary & 168 & 3.66 & .86 & 367 & & \\
\hline & High S. & 92 & 3.58 & .99 & 369 & & \\
\hline \multirow[t]{3}{*}{ Organizing } & Primary S. & 110 & 3.60 & .88 & 2 & 1.876 & .155 \\
\hline & Secondary & 168 & 3.39 & .96 & 367 & & \\
\hline & High S. & 92 & 3.42 & .99 & 369 & & \\
\hline \multirow[t]{3}{*}{ Coordinating } & Primary S. & 110 & 3.38 & .87 & 2 & 1.446 & .237 \\
\hline & Secondary & 168 & 3.19 & .93 & 367 & & \\
\hline & High S. & 92 & 3.24 & .92 & 369 & & \\
\hline \multirow[t]{3}{*}{ Assessment } & Primary S. & 110 & 3.78 & .90 & 2 & 1.946 & .144 \\
\hline & Secondary & 168 & 3.55 & 1.01 & 367 & & \\
\hline & High S. & 92 & 3.64 & .98 & 369 & & \\
\hline
\end{tabular}

$* p<.05$

It can be observed in Table 4 that the teachers' viewpoints on the Competences of Managing the Emotions of Teachers by School Managers vary only in the Decision Making process $\left[F_{(2-367)}=3.400, p<.05\right]$, and there are no variations in the other processes. When the Tukey HSD results are examined it can be observed that the teachers working in primary schools $(M=3.91)$ agree more with the viewpoints on the Competences of Managing the Emotions of Teachers by School Managers than the teachers working in high schools $(\mathrm{M}=3.60)$, and that this difference is significant $(\mathrm{p}<.05)$. 
Table 5. Anova Test Results of the Competences of Managing the Emotions of Teachers by School Managers according to the Duty Variable

\begin{tabular}{|c|c|c|c|c|c|c|c|}
\hline PROCESSES & Duty & $\mathbf{N}$ & $\mathbf{M}$ & SD & df & $\mathbf{F}$ & $\mathbf{p}$ \\
\hline & Teacher & 261 & 3.58 & .88 & 2 & & \\
\hline & Vice Principal & 72 & 4.24 & .62 & 367 & 24.909 & $.000 *$ \\
\hline & Principal & 37 & 4.21 & .60 & 369 & & \\
\hline \multirow[t]{3}{*}{ Planning } & Teacher & 261 & 3.35 & .92 & 2 & & \\
\hline & Vice Principal & 72 & 3.87 & .67 & 367 & 23.366 & $.000^{*}$ \\
\hline & Principal & 37 & 4.20 & .52 & 369 & & \\
\hline \multirow[t]{3}{*}{ Communication } & Teacher & 261 & 3.48 & .89 & 2 & & \\
\hline & Vice Principal & 72 & 4.11 & .63 & 367 & 29.760 & $.000 *$ \\
\hline & Principal & 37 & 4.34 & .55 & 369 & & \\
\hline \multirow[t]{3}{*}{ Organizing } & Teacher & 261 & 3.33 & .99 & 2 & & \\
\hline & Vice Principal & 72 & 3.66 & .76 & 367 & 10.750 & $.000 *$ \\
\hline & Principal & 37 & 3.99 & .60 & 369 & & \\
\hline \multirow[t]{3}{*}{ Coordinating } & Teacher & 261 & 3.09 & .93 & 2 & & \\
\hline & Vice Principal & 72 & 3.54 & .74 & 367 & 19.844 & $.000 *$ \\
\hline & Principal & 37 & 3.93 & .62 & 369 & & \\
\hline \multirow[t]{3}{*}{ Assessment } & Teacher & 261 & 3.44 & 1.01 & 2 & & \\
\hline & Vice Principal & 72 & 4.02 & .66 & 367 & 21.663 & $.000 *$ \\
\hline & Principal & 37 & 4.30 & .68 & 369 & & \\
\hline
\end{tabular}

$$
* p<.01
$$

It can be observed in Table 5 that the teacher and manager viewpoints on the Competences of Managing the Emotions of Teachers by School Managers vary significantly in all management processes according to the Duty variable $(F=24.909$; $23.366 ; 29.760 ; 10.750 ; 19.844 ; 21.663, p<.01)$. When the Tukey HSD results are examined it can be observed that there is a significant difference between the school managers and teachers $(\mathrm{p}<.01)$, and between the vice-managers and teachers $(p<.01)$ in favor of teachers.

Table 6. Anova Test Results of the Competences of Managing the Emotions of Teachers by School Managers according to the Seniority Variable

\begin{tabular}{|c|c|c|c|c|c|c|c|}
\hline PROCESSES & Professional Seniority & $\mathbf{N}$ & $\mathbf{M}$ & SD & df & $\mathbf{F}$ & $\mathbf{p}$ \\
\hline \multirow[t]{5}{*}{ Decision Making } & $1-5$ years & 61 & 3.67 & 1.02 & & & \\
\hline & $6-10$ years & 81 & 3.75 & .91 & 4 & & \\
\hline & $11-15$ years & 75 & 3.86 & .81 & 365 & .648 & .628 \\
\hline & $16-20$ years & 69 & 3.84 & .78 & 369 & & \\
\hline & 21 years and over & 84 & 3.71 & .80 & & & \\
\hline \multirow[t]{5}{*}{ Planning } & $1-5$ years & 61 & 3.33 & 1.08 & & & \\
\hline & $6-10$ years & 81 & 3.43 & .94 & 4 & & \\
\hline & $11-15$ years & 75 & 3.57 & .85 & 365 & 2.111 & .079 \\
\hline & $16-20$ years & 69 & 3.74 & .80 & 369 & & \\
\hline & 21 years and over & 84 & 3.58 & .80 & & & \\
\hline \multirow[t]{5}{*}{ Communication } & $1-5$ years & 61 & 3.49 & 1.07 & & & \\
\hline & $6-10$ years & 81 & 3.59 & .94 & 4 & & \\
\hline & $11-15$ years & 75 & 3.79 & .82 & 365 & 1.756 & .137 \\
\hline & $16-20$ years & 69 & 3.81 & .77 & 369 & & \\
\hline & 21 years and over & 84 & 3.75 & .80 & & & \\
\hline \multirow[t]{5}{*}{ Organizing } & $1-5$ years & 61 & 3.33 & 1.21 & & & \\
\hline & $6-10$ years & 81 & 3.40 & .96 & 4 & & \\
\hline & $11-15$ years & 75 & 3.48 & .82 & 365 & .660 & .620 \\
\hline & 16-20 years & 69 & 3.57 & .87 & 369 & & \\
\hline & 21 years and over & 84 & 3.51 & .88 & & & \\
\hline \multirow[t]{5}{*}{ Coordinating } & $1-5$ years & 61 & 3.02 & 1.08 & & & \\
\hline & $6-10$ years & 81 & 3.09 & .95 & 4 & & \\
\hline & $11-15$ years & 75 & 3.29 & .78 & 365 & 3.658 & $.006^{*}$ \\
\hline & $16-20$ years & 69 & 3.41 & .88 & 369 & & \\
\hline & 21 years and over & 84 & 3.48 & .79 & & & \\
\hline \multirow[t]{5}{*}{ Assessment } & $1-5$ years & 61 & 3.40 & 1.09 & & & \\
\hline & $6-10$ years & 81 & 3.39 & 1.00 & 4 & & \\
\hline & $11-15$ years & 75 & 3.77 & 1.01 & 365 & 4.116 & $.003 *$ \\
\hline & $16-20$ years & 69 & 3.89 & .77 & 369 & & \\
\hline & 21 years and over & 84 & 3.75 & .91 & & & \\
\hline
\end{tabular}

$$
* p<.01
$$

In Table 6, it can be observed that the teacher and manager viewpoints on the Competences of Managing the Emotions of Teachers by School Managers vary according to the Seniority Variable in the Coordinating $\left[F_{(4-465)}=3.658, p<.01\right]$ and Assessment $\left[F_{(4-465)}=4.116, p<.01\right]$ Processes. According to the Tukey HSD results, there is a significant difference in the 
Coordinating Process in terms of the Professional Seniority variable, between the viewpoints of emotion management and between those participants whose Professional Seniority is 21 years and over $(\mathrm{M}=3.48)$ and those whose Professional Seniority is $1-5$ years $(M=3.02)$; and between those whose Professional Seniority is 6-10 years $(M=3.09)$ and those whose Professional Seniority is 21 years and over $(\mathrm{M}=3.02)(p<.01)$. In this context, the teachers who have 21 years and over of Professional Seniority agree more with the viewpoints on the Coordinating Process on the Competences of Managing the Emotions of Teachers by School Managers than those with 1-10 years of Professional Seniority. When the Tukey HSD results are examined in terms of the Assessment Process it can be observed that there are significant differences between the viewpoints of the participants on the Competences of Managing the Emotions of Teachers by School Managers in favor of those whose Professional Seniority is $16-20$ years $(M=3.89)$ and those whose Professional Seniority is $1-5$ years $(M=3.40)$ and $(p<.05)$; and between those whose Professional Seniority is 6-10 years, $(\mathrm{M}=3.39)$ those whose Professional Seniority is $16-20$ years $(\mathrm{M}=3.02)$ and those whose Professional Seniority is $16-20$ years $(p<.01)$. In this context, it was determined that the teachers who have 16-20 years of Professional Seniority agree more with the viewpoints on the Competences of Managing the Emotions of Teachers by School Managers than those who have 1-10 years Professional Seniority.

Table 7. Anova Test Results of Competences of Managing the Emotions of Teachers by School Managers according to Educational Status Variable

\begin{tabular}{|c|c|c|c|c|c|c|c|}
\hline PROCESSES & Educational Status & $\mathbf{N}$ & $\mathbf{M}$ & SD & df & $\mathbf{F}$ & $\mathbf{p}$ \\
\hline \multirow[t]{3}{*}{ Decision Making } & Associate degree & 26 & 3.95 & .62 & 2 & & \\
\hline & Undergraduate & 308 & 3.79 & .85 & 367 & 2.457 & .087 \\
\hline & Postgraduate & 36 & 3.49 & 1.06 & 369 & & \\
\hline \multirow[t]{3}{*}{ Planning } & Associate degree & 26 & 3.78 & .67 & 2 & & \\
\hline & Undergraduate & 308 & 3.55 & .88 & 367 & 3.295 & $.038^{*}$ \\
\hline & Postgraduate & 36 & 3.22 & 1.08 & 369 & & \\
\hline \multirow[t]{3}{*}{ Communication } & Associate degree & 26 & 3.84 & .67 & 2 & & \\
\hline & Undergraduate & 308 & 3.71 & .88 & 367 & 2.545 & .080 \\
\hline & Postgraduate & 36 & 3.39 & 1.01 & 369 & & \\
\hline \multirow[t]{3}{*}{ Organizing } & Associate degree & 26 & 3.72 & .77 & 2 & & \\
\hline & Undergraduate & 308 & 3.48 & .93 & 367 & 4.112 & $.017^{*}$ \\
\hline & Postgraduate & 36 & 3.08 & 1.09 & 369 & & \\
\hline \multirow[t]{3}{*}{ Coordinating } & Associate degree & 26 & 3.68 & .70 & 2 & & \\
\hline & Undergraduate & 308 & 3.28 & .90 & 367 & 6.826 & $.001 *$ \\
\hline & Postgraduate & 36 & 2.84 & 1.02 & 369 & & \\
\hline \multirow[t]{3}{*}{ Assessment } & Associate degree & 26 & 3.82 & .84 & 2 & & \\
\hline & Undergraduate & 308 & 3.66 & .96 & 367 & 1.899 & .151 \\
\hline & Postgraduate & 36 & 3.37 & 1.16 & 369 & & \\
\hline
\end{tabular}

$* p<.01$

According to the Educational Status variable in Table 7, when the viewpoints of the teachers and school managers are examined, it can be observed that there are significant differences in terms of the Planning $\left[F_{(2-367)}=3.295, p<.05\right]$, Organizing $\left[F_{(2-367)}=4.112, p<.05\right]$ and Coordinating $\left[F_{(2-367)}=6.826, p<.01\right]$ Processes between those who have Associate Degrees, Undergraduate degrees and Postgraduate Degrees. When the Tukey HSD results are examined it can be observed that the participants who have Associate Degrees and Undergraduate Degrees agree more with the viewpoints on the Competences of Managing the Emotions of Teachers by School Managers than those with Postgraduate Degrees.

\section{Results and Discussion}

In this study, the competences of the school managers in managing the emotions of teachers working in the city of Uşak were determined by using the teachers' viewpoints. When the teachers' viewpoints on the Competences of Managing the Emotions of Teachers by School Managers are examined in terms of Management Processes, it can be observed that the teachers evaluate the competences of the school managers in the Decision Making, Planning, Communication, Organizing and Assessment Processes in a very positive manner.

It may be considered that the perceived levels of the competences of the school managers on this topic are high, and this situation creates a positive medium in terms of school management. The findings reported by Çoruk [9], who conducted a study in universities, do not show any similarities with the findings of the present study. It may be claimed that this difference stems from the institutions. In this context, it may be considered that the structure and the medium of the organizations influence the emotion management behaviors of the managers. The Coordinating Process is considered to be a process where the teachers agree with the expressions at the lowest level of the competences of the school managers in managing the emotions of teachers. The Decision Making process, on the other hand, attracts attention as a process where the teachers agree at the highest level about the viewpoints of the Competences of Managing the Emotions of Teachers by School Managers. The Decision Making process is known as the heart of the management process. When the findings of this study are considered, it may be claimed that the school managers take the emotions of the teachers into account 
when they are making decisions, and they deal with the expectations of the teachers in this context. It may be considered that the school managers are aware of the fact that ignoring emotions when trying to solve problems will create negative emotions in the teachers. As Bursalıoglu [7] expressed, the managers must realize that one of the problems observed in the Decision Making process is the psychological factor, and emotions must be dealt with. School managers must include their employees in this process, motivate them and deal with their emotions and behaviors.

It can be observed that the viewpoints of the female and male teachers on the Competences of Managing the Emotions of Teachers by School Managers vary in terms of the Decision Making, Planning, Communication, Coordinating and Assessment Processes. It was determined that the female participants generally evaluate the Competences of Managing the Emotions of Teachers by School Managers in a more negative manner. According to the findings of various studies that([30], [23], [26]) conducted on the Competences of School Managers in Turkey, male teachers evaluate school managers in a more positive manner than female teachers. When the fact that the majority of school managers in Turkey are male is considered, it may be claimed that male teachers and managers establish more positive, sincere and real communications; and depending on this, male teachers evaluate their school managers in a more positive manner.

It was observed in the study that the viewpoints on Competences of Managing the Emotions of Teachers by School Managers vary in the areas except for the Assessment Process. It was observed that Class Teachers evaluate the competences of the school managers in emotion management in a more positive manner in terms of Decision Making, Planning, Communication, Organizing and Coordinating Processes.

It was observed in this study that the viewpoints of teachers working in primary schools vary in the topic of the Competences of the School Managers on Emotion Management only in the field of the Decision Making process when compared with teachers working in secondary and high schools; and there are no variations in the other processes. However, it was also determined in terms of all the processes that teachers working in primary schools have more positive viewpoints on the emotional management competences of their school managers. According to the Appointment of the School Managers Regulation in Turkey (2016), managers in primary schools are appointed from among class teachers, and managers in high schools are appointed from among other branch teachers. Babaoğlan [5] conducted a study entitled "Emotional Intelligence of School Managers", and revealed that the managers' emotional intelligence points varied according to whether they are class teachers or they have other branches. In this context, it was concluded that school managers who come from class teacher branches have higher emotional intelligence levels than those from other branches. When the fact that how well managers control their emotions depends on their emotional intelligence level [12] is considered, the findings of the present study overlap with the findings of a study conducted by Babaoğlan [5]. Similarly, Titrek, Bayrakçı and Zafer [26] conducted a study and reported that primary school managers were found to be more successful than general and vocational high school managers in terms of emotional management competences.

It was concluded in this study that the teacher viewpoints on the competences of managing the emotions of teachers by managers in terms of management processes vary according to the duty and management process variables. It was also revealed that teachers perceive the emotional management competences of their school managers in a more negative manner than principals and vice-principals. This finding may be interpreted that the school managers who are included in this study's range consider themselves to have a more competent manner in terms of managing emotions, and that school managers perform their self-assessments in a more positive manner. Y1ldiz [31] conducted a study and reported that there were significant differences between the viewpoints of teachers and school managers, and that school managers consider themselves in a more positive light than teachers.

In general, and in terms of single management processes, when the viewpoints of the teachers on the competences of the school managers on emotional management are considered, it can be observed that teachers who are new to their jobs (1-10 years) evaluate the emotional management behaviors of their school managers in a more negative manner. It may be claimed that teachers who are new to their jobs do not have the opportunity to observe different managers or to obtain adequate experience; therefore, they have higher expectations regarding being cared for in terms of their emotions, expressing their emotions and receiving feedback from their organization.

In general, it was observed that teachers with postgraduate degrees evaluate the emotional management behaviors of their school managers in a more negative manner when compared with teachers who have associate degrees and undergraduate degrees, and there are variations in some processes. When the fact that the knowledge levels of teachers with postgraduate degrees in emotions and school management are high is considered it may be concluded that they want to work with managers who are aware of their emotions and who can control and guide the emotions of other people, and that their expectations regarding this topic are high.

Based on this study's findings, the following recommendations may be made:

School managers should not adopt only a rational viewpoint during management processes; they should also consider the existence of the emotions of their teachers, and encourage them to share their feelings and organize activities to create a positive organization medium and to make their employees experience positive feelings.

School managers should receive training on how to 
manage their own emotions and those of other individuals.

\section{Note}

*The abstract of this paper was presented at 2nd International Conference on Lifelong Learning and Leadership for All (ICLEL-16), in Liepaja on July, 21-23, 2016.

\section{REFERENCES}

[1] Alvinius, A., Boström, M. E. \& Larsson, G. (2015). Leaders as emotional managers: Emotion management in response organisations during a hostage taking in a Swedish prison. Leadership \& Organization Development Journal, 36(6), 697-711.

[2] Andrieş, A. M. (2009). Emotions management within organizations. The Annals of 'Dunerea de Jos' University, Economics and Informatics, ISSN 1584-0409, 17-33.

[3] Argon, T. (2015). Views of teachers regarding whether school administrators take teachers' state of emotions into consideration or not. The Journal of SAU Education Faculty 15(1), 377-404.

[4] Ashkanasy, N. M. \& Daus, C. S. (2002). Emotion in the workplace: The new challenge for managers. The Academy of Management Executive, 16(1), 76-86.

[5] Babaoğlan, E. (2010). Emotional intelligence in school administrators. The Journal of Ahi Evran University Educational Faculty, 11(1), 119-136.

[6] Bakalım, O. \& Tasdelen-Karçkay, A. (2015). Positive and negative affect as predictors of family life satisfaction. International Journal of Human Sciences, 12, 1130-1137. Doi:10.14687/ijhs.v12i1.3251

[7] Bursalıoğlu, Z. (2005). New structure and behaviour on school management. (13. Edition). Ankara: Pegem A Press.

[8] Brotheridge, C. M. \& Lee, R. T. (2008). The emotions of managing: An introduction to the special issue. Journal of managerial psychology, 23(2), 108-117.

[9] Çoruk, A. (2012). Managers'emotion management behaviours in terms of management processes. Doctoral Thesis, Çanakkale Onsekiz Mart University.

[10] Çoruk, A. \& Akçay, R. C. (2012). Scale of managers'emotion management behaviours in terms of management processes: A validity and reliability study. Journal of Buca Education Faculty, 33, 81-94.

[11] George, J. M. (2000). Emotions and leadership: The role of emotional intelligence. Human relations, 53(8), 1027-1055.

[12] Goleman, D., Boyatzis, R. \& McKee, A. (2014). The new leaders. (Tr. F. Nayır ve O. Deniztekin). Varlık Press. (Release date the original book 2002)

[13] Grama, B. \& Boțone, D. (2009). The role of emotions in organizational behaviour. Annals of The University of Petroşani, Economics, 9(3), 315-320.
[14] Gross, J. J. \& Thompson, R. A. (2007). Emotion regulation: Conceptual foundations. Gross J..J (Eds.) Handbook of Emotion Regulation (pp.3-26). New York: Guilford.

[15] Humphrey, R. H., Pollack, J. M. \& Hawver, T. (2008). Leading with emotional labor. Journal of Managerial Psychology, 23(2), 151-168.

[16] Keskin, H., Akgün, A. E. \& Y1lmaz, S. (2013). Emotional intelligence and emotional skills within organizations Istanbul: Der Press.

[17] Korkmaz, M. (2005). The effect of emotions and leadership styles on teacher's performance. Educational Administration: Theory and Practice, 11(3), 401-422.

[18] Kozak, M. A. \& Genç, V. (2014). The importance of emotion management emerging for the prevention of resistance in the change process: A perspective for Service Businesses. Journal of Economics and Management Sciences, 1(2).

[19] Mayer, J. D. \& Salovey, P. (1997). What is emotional intelligence? J. D. Mayer \& P. Salovey (Eds.), Emotional development and emotional intelligence. New York: Basic Books.

[20] Niven, K. (2015). Why do people engage in interpersonal emotion regulation at work?. Organizational Psychology Review, 2041386615612544.

[21] Niven, K., Totterdell, P. \& Holman, D. (2009). A classification of controlled interpersonal affect regulation strategies. Emotion, 9(4), 498-509.

[22] Özçelik, H., Langton, N. \& Aldrich, H. (2008). Doing well and doing good: The relationship between leadership practices that facilitate a positive emotional climate and organizational performance. Journal of Managerial Psychology, 23(2), 186-203.

[23] Öztekin, A. (2006). The evaluation of the emotional intelligence skills using levels on school administration of the administrators working on secondary school education. Masters' Thesis Balıkesir University, Institute of Social Science, Department of Educational Sciences

[24] Pedersen, P. P. (2001). Managing emotion in organisational change: Emotion management as power Downloaded on 18 September 2015 from:

http://www.mngt.waikato.ac.nz/ejrot/cmsconference/2001/P apers/Change0and\%20Organisation/Pedersen.pdf

[25] Thiel, C., Griffith, J. \& Connelly, S. (2015). Leader-Follower Interpersonal Emotion Management Managing Stress by Person-Focused and Emotion-Focused Emotion Management. Journal of Leadership \& Organizational Studies, 22(1), 5-20.

[26] Titrek, O., Bayrakçı, M. \& Zafer, D. (2009).The perceptions of school managers and teachers' on school managers' emotion management competenciec. The Journal of Mehmet Akif Ersoy University Educational, 9(18), 55-73.

[27] Toegel, G., Kilduff, M. \& Anand, N. (2013). Emotion helping by managers: An emergent understanding of discrepant role expectations and outcomes.Academy of Management Journal, 56(2), 334-357.

[28] Töremen, F. \& Çankaya, I. (2008). An effective approach at management: Emotional management. Journal of Theoretical Educational Science, 1 (1), 33-47. 
[29] Türkay, O., Ünal, A. \& Taşar, O. (2011). The effects of emotional labor on job commitment under the determination of motivational and structural variables. International Journal of Management Economics and Business, 7(14), 201-222.

[30] Uyğur, G. (2014). Communication efficiency of primary and secondary school administrators. Masters' Thesis, Okan University, Institute of Social Science, Department of Business, Izmir.
[31] Y1ld1z, A. İ. (2013). An analysis of relation between the amount of school managers ability to use their emotional intelligence competence on profession and educational leadership behaviours. Masters' Thesis, Yüzüncü Y1l University, Institute of Social Science, Department of Educational Sciences.

[32] Pescosolido, A. T. (2002). Emergent leaders as managers of group emotion. Leadership Quarterly, 13, 583-599. 